\title{
Novel Spirodihydrobenzofuranlactams as Antagonists of Endothelin and as Inhibitors of HIV-1 Protease Produced by Stachybotrys sp.
}

\section{Structure Determination}

\author{
Barbara E. Roggo*, Paul Hug ${ }^{\dagger}$, Serge Moss ${ }^{\dagger}$, A. Stämpfli ${ }^{\dagger}$, \\ Hans-Peter Kriemler ${ }^{\dagger}$ and Heinrich H. Peter \\ Core Drug Discovery Technologies, Pharmaceutical Division, Ciba-Geigy Limited, \\ CH-4002 Basel, Switzerland \\ ${ }^{\dagger}$ Research Services Physics Department, Spectroscopy, Ciba-Geigy Limited, \\ CH-4002 Basel, Switzerland
}

(Received for publication January 8, 1996)

The structures of six novel spirodihydrobenzofuranlactams I $\sim$ VI $(1 \sim 6)$ were determined by spectroscopic methods.

Six novel spirodihydrobenzofuranlactams I $\sim$ VI $(1 \sim$ 6) (Fig. 1) have been identified in extracts of two different Stachybotrys species as antagonists of endothelin and as inhibitors of HIV-1 protease. In a recently published paper $^{1)}$ we described the fermentation, isolation and bio- logical properties of these secondary metabolites $1 \sim 6$. Besides this novel class of the spirodihydrobenzofurans including the lactams $1 \sim 4,6$ and the imide 5 the known spirodihydrobenzofuranalcohol L-671776 ${ }^{2)}$ was isolated. This inositol-phosphate phosphatase and HIV-1 protease

Fig. 1. Chemical structures of six new spirodihydrobenzofuranlactams I VI (1 6) and Mer-NF5003E (7).

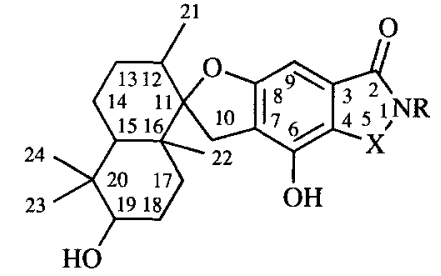

\begin{tabular}{|c|c|c|c|}
\hline & & $X$ & $\mathrm{R}$ \\
\hline 1 & I & $\mathrm{CH}_{2}$ & $\mathbf{H}$ \\
\hline 2 & II & $\mathrm{CH}_{2}$ & ${ }^{1 "} \mathrm{CH}_{2}{ }^{2 "} \mathrm{CH}_{2} \mathrm{OH}$ \\
\hline 3 & III & $\mathrm{CH}_{2}$ & ${ }^{1 "} \mathrm{CH}_{2}{ }^{2 "} \mathrm{CH}_{2}{ }^{3 "} \mathrm{CH}_{2}{ }^{4 \prime} \mathrm{CH}_{2}{ }^{5 "} \mathrm{COOH}$ \\
\hline 4 & IV & $\mathrm{CH}_{2}$ & ${ }^{2 "} \mathrm{CH}\left({ }^{1 "} \mathrm{COOH}\right)^{3 "} \mathrm{CH}_{2}{ }^{4}{ }^{4} \mathrm{CH}_{2}{ }^{5 "} \mathrm{COOH}$ \\
\hline 5 & V & $\mathrm{C}=\mathrm{O}$ & $\mathrm{H}$ \\
\hline
\end{tabular}

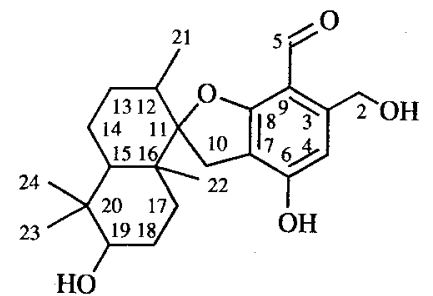

7

Mer-NF5003E

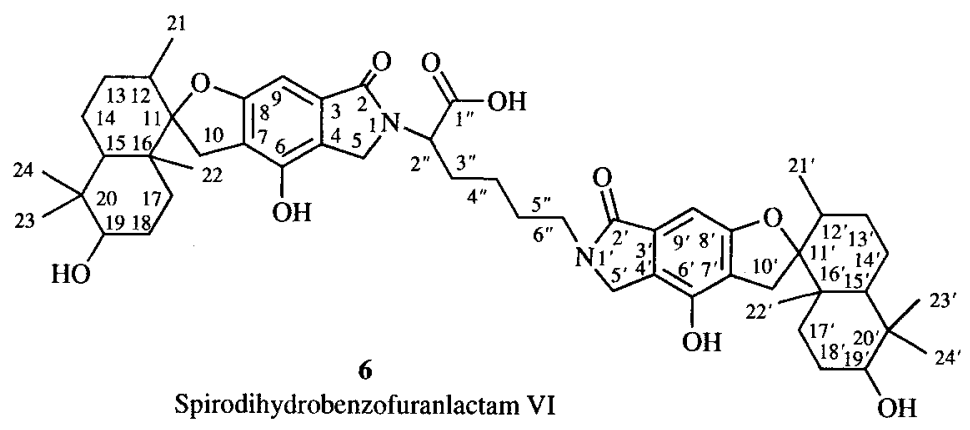


inhibitor L-671776 is structurally related to $\mathrm{K}-76^{3)}$ and to the described avian myeloblastosis virus inhibitors Mer-NF5003B, E (7) and $\mathrm{F}^{4)}$. In this paper we will resent the structure elucidation and physico-chemical properties of the spirodihydrobenzofuranlactams $1 \sim 6$.

The FTIR spectrum of the spirodihydrobenzofur anlactam 1, prepared as a potassium bromide pellet, is shown in Fig. 2. The spectrum is representative for all spirodihydrobenzofuranlactams and shows absorption bands at $3388(\mathrm{OH}, \mathrm{NH}$ and moisture), 2936, 2874 (aliphatic chain), 1682 (lactam $\mathrm{C}=\mathrm{O}$ ), 1466 (mainly $\mathrm{CH}$ and aromatic ring), 1388, $1348\left(\mathrm{C}-\mathrm{N}, \mathrm{CH}_{3}\right), 1085(\mathrm{C}-\mathrm{O})$, 1008,960 and $773 \mathrm{~cm}^{-1}$. The FTIR spectrum of the pseudosymmetric compound 6 (Fig. 3) is very similar to the spectrum of compound $\mathbf{1}$ as it is the case for all other spirodihydrobenzofuranlactams.

The molecular weights of the spirodihydrobenzofuranlactams ( $1 \sim \mathbf{4}$ and 6$)$ were confirmed by observing the corresponding quasi-molecular ion peaks at $\mathrm{m} / \mathrm{z}$ $386(\mathrm{M}+\mathrm{H})^{+}$for compound $\mathbf{1}, m / z 430(\mathrm{M}+\mathrm{H})^{+}$for compound 2, $m / z 486(\mathrm{M}+\mathrm{H})^{+}$for compound 3, $\mathrm{m} / \mathrm{z}$ $516(\mathrm{M}+\mathrm{H})^{+}$for compound $4, m / z 400(\mathrm{M}+\mathrm{H})^{+}$for compound 5 and $m / z 883(\mathrm{M}+\mathrm{H})^{+}$for compound 6 in the individual FAB-MS spectra. In addition exact mass measurement in the HR-FAB mode confirmed the elemental compositions of $\mathrm{C}_{23} \mathrm{H}_{31} \mathrm{NO}_{4}$ for $1, \mathrm{C}_{25} \mathrm{H}_{35} \mathrm{NO}_{5}$ for $2, \mathrm{C}_{28} \mathrm{H}_{39} \mathrm{NO}_{5}$ for $3, \mathrm{C}_{28} \mathrm{H}_{37} \mathrm{NO}_{8}$ for $4, \mathrm{C}_{23} \mathrm{H}_{29} \mathrm{NO}_{5}$ for 5 and $\mathrm{C}_{52} \mathrm{H}_{70} \mathrm{~N}_{2} \mathrm{O}_{10}$ for the spirodihydrobenzo-

Fig. 2. FTIR spectrum of spirodihydrobenzofuranlactam I (1).

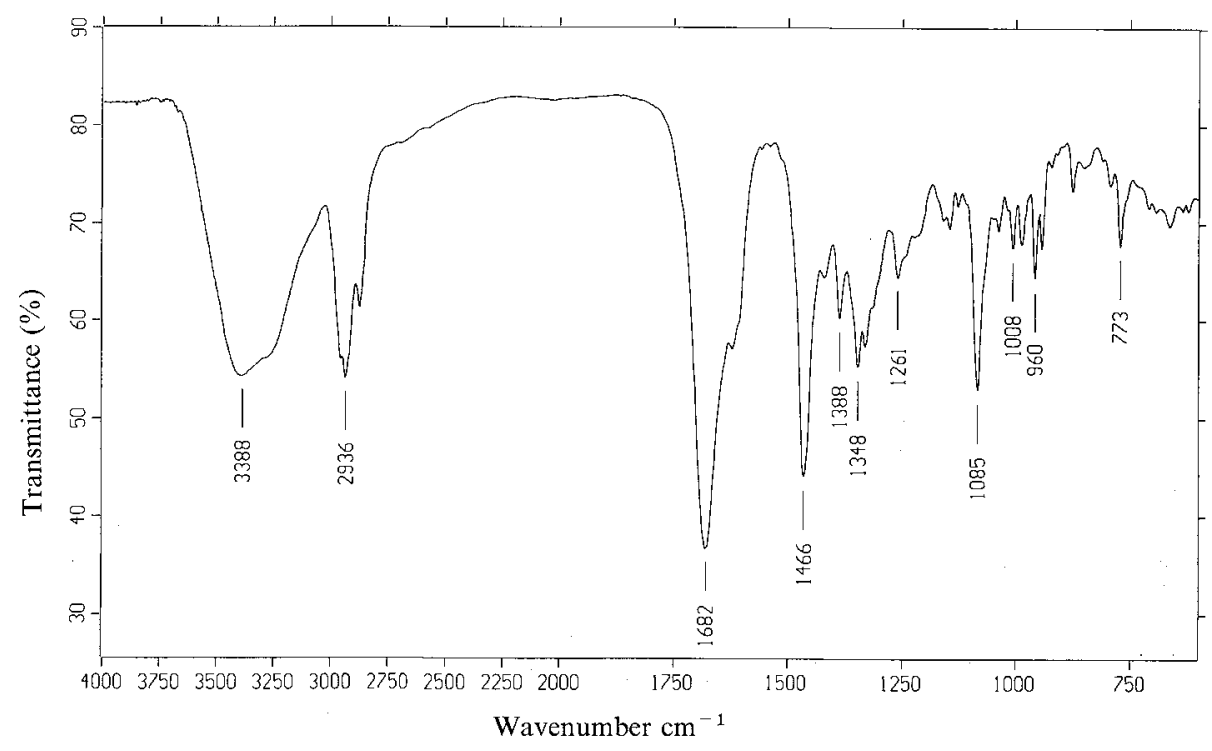

Fig. 3. FTIR spectrum of spirodihydrobenzofuranlactam VI (6).

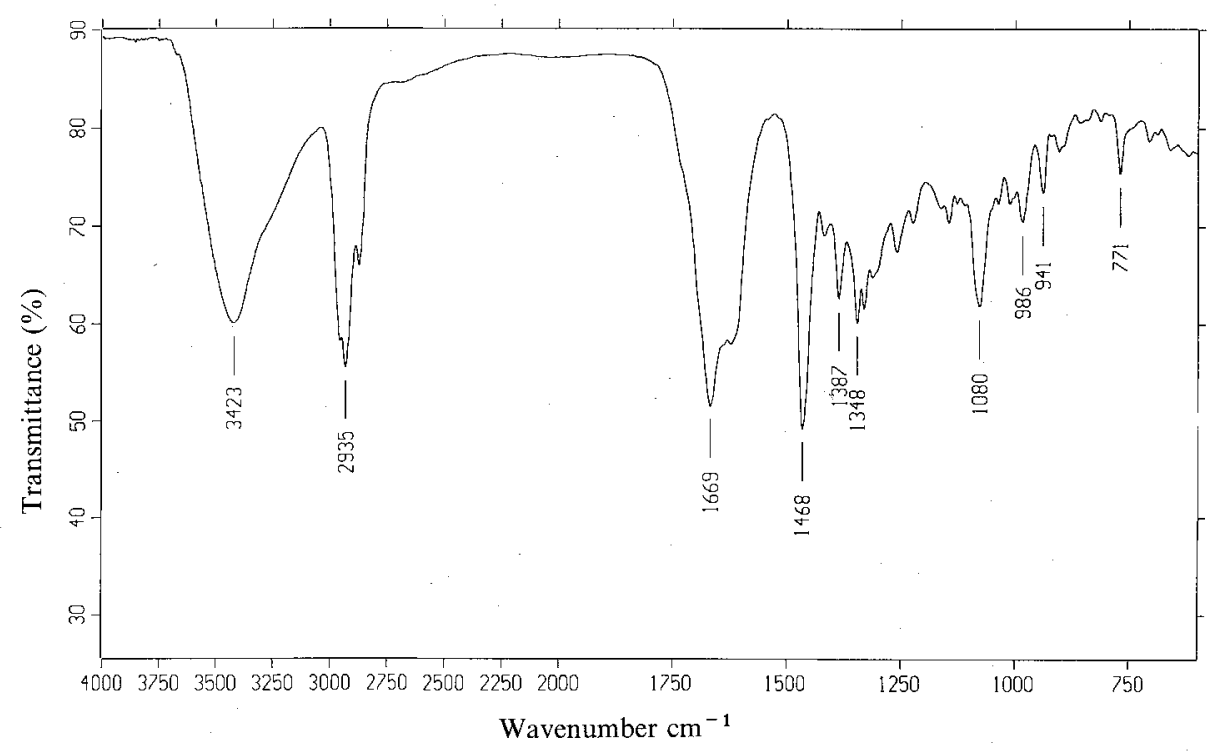


Table 1. ${ }^{1} \mathrm{H}$ NMR chemical shifts of spirodihydrobenzofuranlactams I VI (1 $\left.\sim 6\right)$ and Mer-NF5003E (7).

\begin{tabular}{|c|c|c|c|c|c|c|c|}
\hline Proton number & $1^{\mathrm{a}}$ & $2^{\mathrm{b}}$ & $3^{\mathrm{b}}$ & $4^{\mathrm{b}}$ & $5^{\mathrm{c}}$ & $6^{\mathrm{b}}$ & 7 (i) \\
\hline $1,1^{\prime}$ & $\begin{array}{l}8.00 \mathrm{~s}, \mathrm{br} \\
(\mathrm{NH})\end{array}$ & - & - & - & $\begin{array}{l}9.0 \mathrm{~s}, \mathrm{br} \\
(\mathrm{NH})\end{array}$ & - & - \\
\hline $5,5^{\prime}$ & $4.18 \mathrm{~d}$ & $4.55 \mathrm{~d}$ & $4.48 \mathrm{~d}$ & $4.4 \sim 4.8 \mathrm{~m}$ & - & $4.2 \sim 4.8 \mathrm{~m}$ & $10.3 \mathrm{~s}(5)$ \\
\hline $2^{\prime \prime \mathrm{f}}, 2^{\prime \prime \mathrm{g}}$ & $4.10 \mathrm{~d}$ & $4.45 \mathrm{~d}$ & $4.30 \mathrm{~d}$ & & & & $4.71 \mathrm{~s}(2)$ \\
\hline $6,6^{\prime}$ & $\begin{array}{l}9.3 \mathrm{~s}, \text { br } \\
(\mathrm{OH})\end{array}$ & - & - & - & $\begin{array}{l}10.0 \mathrm{~s}, \mathrm{br} \\
(\mathrm{OH})\end{array}$ & 一 & - \\
\hline $9,9^{\prime}$ & $6.55 \mathrm{~s}$ & $6.68 \mathrm{~s}$ & $6.66 \mathrm{~s}$ & $6.68 \mathrm{~s}$ & $6.82 \mathrm{~s}$ & $6.68 \mathrm{~s}, 6.66 \mathrm{~s}$ & $6.62 \mathrm{~s}(4)$ \\
\hline \multirow[t]{2}{*}{$10,10^{\prime}$} & $3.10 \mathrm{~d}$ & $3.25 \mathrm{~d}$ & $3.20 \mathrm{~d}$ & $3.25 \mathrm{~d}$ & $3.15 \mathrm{~d}$ & $3.20 \mathrm{~d}$ & $3.26 \mathrm{~d}$ \\
\hline & $2.75 \mathrm{~d}$ & $2.85 \mathrm{~d}$ & $2.85 \mathrm{~d}$ & $2.85 \mathrm{~d}$ & $2.78 \mathrm{~d}$ & $2.83 \mathrm{~d}$ & $2.79 \mathrm{~d}$ \\
\hline \multirow[t]{2}{*}{$19,19^{\prime}$} & $\begin{array}{l}3.78 \mathrm{~s}, \mathrm{br} \\
(\mathrm{OH})\end{array}$ & - & - & - & $\begin{array}{l}3.37 \mathrm{~s}, \mathrm{br} \\
(\mathrm{OH})\end{array}$ & - & - \\
\hline & $3.20 \mathrm{~m}$ & $3.35 \mathrm{t}$ & $3.35 \mathrm{~m}$ & $\mathrm{~h}$ & $2.6 \mathrm{t}$ & h & 3.33 \\
\hline $12 \sim 15,17 \sim 18$ & $1.4 \sim 2.1 \mathrm{~m}$ & $1.5 \sim 2.15 \mathrm{~m}$ & $1.4 \sim 2.18 \mathrm{~m}$ & $1.3 \sim 2.2 \mathrm{~m}$ & $1.3 \sim 2.2 \mathrm{~m}$ & $1.3 \sim 2.25 \mathrm{~m}$ & $1.89(12)$ \\
\hline $12^{\prime} \sim 15^{\prime}$ & & & & & & & $1.62(13)$ \\
\hline $17^{\prime} \sim 18^{\prime}$ & & & & & & & $1.63(14)$ \\
\hline $3^{\prime \prime \mathrm{e}}, 3^{\prime \prime \mathrm{f}}, 4^{\prime \prime \mathrm{f}}$ & & & & & & & $2.25(15)$ \\
\hline \multirow{2}{*}{$3^{\prime \prime g}, 4^{\prime \prime g}, 5^{\prime \prime g}$} & & & & & & & $1.05,1.96(17)$ \\
\hline & & & & & & & $1.62,1.96(18)$ \\
\hline $21,21^{\prime}$ & $0.66 \mathrm{~d}$ & $0.75 \mathrm{~d}$ & $0.72 \mathrm{~d}$ & $0.75 \mathrm{~d}$ & $0.73 \mathrm{~d}$ & $0.72 \mathrm{~d}$ & $0.77 \mathrm{~d}$ \\
\hline $22,22^{\prime}$ & $0.98 \mathrm{~s}$ & $1.08 \mathrm{~s}$ & $1.08 \mathrm{~s}$ & $1.08 \mathrm{~s}$ & $1.00 \mathrm{~s}$ & $1.03 \mathrm{~s}$ & $1.05 \mathrm{~s}$ \\
\hline $23,23^{\prime}$ & $0.90 \mathrm{~s}$ & $0.98 \mathrm{~s}$ & $0.98 \mathrm{~s}$ & $0.98 \mathrm{~s}$ & $1.00 \mathrm{~s}$ & $0.98 \mathrm{~s}, 0.96 \mathrm{~s}$ & $0.99 \mathrm{~s}$ \\
\hline $24,24^{\prime}$ & $0.80 \mathrm{~s}$ & $0.90 \mathrm{~s}$ & $0.90 \mathrm{~s}$ & $0.90 \mathrm{~s}$ & $0.87 \mathrm{~s}$ & $0.90 \mathrm{~s}, 0.88 \mathrm{~s}$ & $0.88 \mathrm{~s}$ \\
\hline \multirow[t]{2}{*}{$1^{\prime \prime d}, 2^{\prime \prime d}$} & & $3.80 t$ & & & & & \\
\hline & & $3.70 t$ & & & & & \\
\hline $1^{\prime \prime e}, 4^{\prime \prime e}$ & & & $4.08 \mathrm{~m}$ & & & & \\
\hline & & & $3.6 \mathrm{~m}$ & & & & \\
\hline $2^{\prime \prime \mathrm{e}}$ & & & $2.32 \mathrm{t}$ & & & & \\
\hline $6^{\prime \prime \mathrm{s}}$ & & & & & & $3.55 \mathrm{~m}$ & \\
\hline
\end{tabular}

Chemical shifts given in ppm. ${ }^{a}$ Solvent DMSO, $80^{\circ} \mathrm{C}$, ${ }^{\mathrm{b}}$ solvent $\mathrm{CD}_{3} \mathrm{OD},{ }^{\mathrm{c}}$ solvent $\mathrm{DMSO} / \mathrm{CDCl}_{3},{ }^{\mathrm{d}} 1^{\prime \prime}, 2^{\prime \prime}$ for $2,{ }^{\mathrm{e}} 1^{\prime \prime}, 2^{\prime \prime}, 3^{\prime \prime}, 4^{\prime \prime}$ for $3,{ }^{\mathrm{f}} 2^{\prime \prime}, 3^{\prime \prime}, 4^{\prime \prime}$ for $4,{ }^{\mathrm{g}} 2^{\prime \prime}, 3^{\prime \prime}, 4^{\prime \prime}, 5^{\prime \prime}, 6^{\prime \prime}$ for $\mathbf{6}^{\mathrm{h}}{ }^{\mathrm{h}}$ hidden under solvent peak, ${ }^{\mathrm{i}}$ proton number.

furanlactam 6.

The shift assignments in the ${ }^{1} \mathrm{H}$ NMR spectra of all spirodihydrobenzofuranlactams $(\mathbf{1} \sim 6)$ are summarized in Table 1. The numberings of the carbon atoms of the different compounds $\mathbf{1} \sim \mathbf{6}$ are given in Fig. 1. COSY and NOE experiments on compound 1 allowed the attribution of all signals in the ${ }^{1} \mathrm{H}$ NMR spectrum and established the definitive stereochemistry of this compound (see Fig. 4). The only two protons of the five-membered lactam ring at carbon atom $\mathrm{C}-5$ form a typical $\mathrm{AB}$ system for the compounds $\mathbf{1} \sim \mathbf{4}$ and $\mathbf{6}$ and have chemical shifts in the range of 4.1 to $4.8 \mathrm{ppm}$. The protons at $\mathrm{C}-5$ of the compounds 1 3 show typical coupling constants of $J=18 \mathrm{~Hz}$, while the coupling constants in the ${ }^{1} \mathrm{H}$ NMR spectrum of the spirodihydrobenzofuranlactams 4 and 6 cannot be determined (multiplets). This signal is of course absent in the ${ }^{1} \mathrm{H}$ NMR spectrum of the imide 5 .

The protons of the methylene group at the carbon atom $\mathrm{C}-10$ in the five-membered ring of the spirocyclic ring system belong also to an $\mathrm{AB}$ system, chemical shifts of 2.7 to $3.2 \mathrm{ppm}$ were measured and the coupling constants of these methylene protons are in the range of $J=18 \mathrm{~Hz}$ for all compounds $1 \sim 6$. The protons at
Fig. 4. Relevant NOEs of spirodihydrobenzofuranlactam I (1).

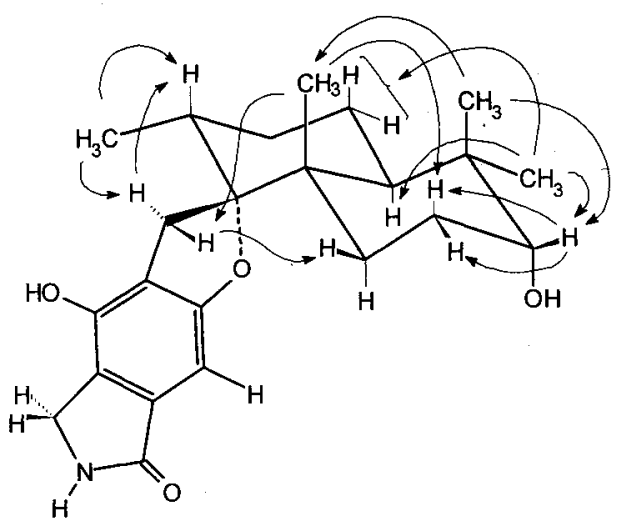

C-10 showed NOEs to protons at C-12, C-21 and the equatorial proton at $\mathrm{C}-17$. This finding determined the stereochemistry of the spirocarbon atom C-11.

Depending on the solvent system used the aromatic proton at C-9 showed a chemical shift range between $6.55 \mathrm{ppm}$ and $6.82 \mathrm{ppm}$ for all six compounds. The absence of an NOE from the proton at C-9 to the methylene protons at C-5 or C-10 established the sub- 
stitution on the aromatic ring. Most of the signals of the protons in the ${ }^{1} \mathrm{H}$ NMR spectrum of $\mathbf{6}$ do not appear as doublets due to the pseudosymmetry of the spirodihydrobenzofuranlactam VI (6). However, metabolite 6 showed two distinct singlets at $6.66 \mathrm{ppm}$ and $6.68 \mathrm{ppm}$ for the protons at C-9 and C-9', due to the pseudosymmetry of the bridge between the two spirodihydrobenzofuranlactam moieties. The proton signals of the methyl groups at C-23, C-24 and C-23', C-24' respectively appeared also as singlets at $0.98 \mathrm{ppm}, 0.90 \mathrm{ppm}$ and at $0.96 \mathrm{ppm}, 0.88 \mathrm{ppm}$ respectively. The methyl groups at $\mathrm{C}-21$ and $\mathrm{C}-21^{\prime}$ showed a doublet at $0.72 \mathrm{ppm}$ and the methyl groups at $\mathrm{C}-22$ and $\mathrm{C}-22^{\prime}$ a singlet at $1.03 \mathrm{ppm}$ for metabolite 6 .

The chemical shifts of the four methyl groups for the compounds $1 \sim 5$ are in the same range as those for the spirodihydrobenzofuranlactam Vl (6) and have been attributed based on NOE experiments. The assignments are well in accordance with the data reported in literature for the related sesquiterpenoids Mer-NF5003B, E and $\mathrm{F}^{4}$. The relevant NOEs for compound 1 are given in Fig. 4. The methyl groups $\mathrm{C}-23$ and $\mathrm{C}-24$ could be differentiated by the observation of NOEs from the protons at $\mathrm{C}-23$ to the methine proton $\mathrm{C}-15$ and from the protons at $\mathrm{C}-24$ to those of the methyl group of C-22. The equatorial position of the methyl group at C-21 could be proven by the detection of an NOE between the protons of $\mathrm{C}-21$ and $\mathrm{C}-10$ and by the absence of an NOE to the protons of $\mathrm{C}-22$.

The signal of the methine proton at $\mathrm{C}-19$ appears as a multiplet in the range of $2.6 \mathrm{ppm}$ to $3.35 \mathrm{ppm}$ in the individual ${ }^{1} \mathrm{H}$ NMR spectra. The axial position of thre hydroxy group at $\mathrm{C}-19$ was determined by the presence of NOEs from the proton at $\mathrm{C}-19$ to the protons at $\mathrm{C}-23$ and C-24 as well as both methylene protons at C-18. In addition the magnitudes of the NOEs to the methyl groups at C-23 and C-24 were comparable and they were also about the same for the two protons at C-18.

The remaining protons of the decalene moieties showed chemical shifts between $1.3 \sim 2.25 \mathrm{ppm}$ and could not be assigned individually.

The spirodihydrobenzofuranlactam II (2) showed two additional triplets at 3.8 and $3.7 \mathrm{ppm}$ with a coupling constant of $J=6 \mathrm{~Hz}$ for the protons of the side chain at $\mathrm{C}-1^{\prime \prime}$ and $\mathrm{C}-2$. In the ${ }^{1} \mathrm{H}$ NMR spectrum of metabolite 3 the multiplets at $4.08 \mathrm{ppm}$ and $3.6 \mathrm{ppm}$ were assigned to the protons of $\mathrm{C}-\mathrm{I}^{\prime \prime}$ and $\mathrm{C}-4^{\prime \prime}$ respectively, the triplet at $2.32 \mathrm{ppm}$ to those of $\mathrm{C}-2^{\prime \prime}$ and the multiplets between $1.4 \sim 2.18$ ppm to those of C-3".

Only the proton of C-6" of compound 6 showed an additional multiplet at $3.55 \mathrm{ppm}$ in the ${ }^{1} \mathrm{H}$ NMR spectrum compared to that one of metabolite 1 or 5 . The remaining methine or methylene protons of the bridge of 6 were assigned to the multiplets at $4.2 \sim 4.8 \mathrm{ppm}$ (methine protons) or to the multiplets at $1.3 \sim 2.25 \mathrm{ppm}$ (methylene protons), as it is also the case for the methine protons $(4.4 \sim 4.8 \mathrm{ppm})$ and methylene protons $(1.3 \sim$ $2.2 \mathrm{ppm}$ ) of the side chain of compound 4 .

The ${ }^{13} \mathrm{C}$ NMR spectra of the spirodihydrobenzofuranlactams 1, 3 and 6 were recorded at $100 \mathrm{MHz}$ and the detailed data of these spectra are listed in Table 2. The interpretation of HSQC spectra of all three compounds and $\mathrm{HMBC}$ measurements of compound 1 allowed the full assignments of the signals in the ${ }^{13} \mathrm{C}$ NMR spectra. In the ${ }^{13} \mathrm{C}$ NMR spectra of all compounds the chemical shifts of the carbon atoms in the spirodihydrobenzofuranlactam core structure are well in accordance with the proposed structures.

The assignments of the ${ }^{13} \mathrm{C}$ NMR chemical shifts for C-2 and C-2' to C-9 and C-9' for the metabolites 1, 3 and 6 are based on the results obtained for the spirodihydrobenzofuranlactam I (1). In the ${ }^{13} \mathrm{C}$ NMR spectrum of compound 1 the signals were attributed as follows: $174.11 \mathrm{ppm}$ to the lactam carbonyl C-2, $157.78 \mathrm{ppm}$ and $155.20 \mathrm{ppm}$ to the carbon atoms C-6 and C-8 carrying an oxygen, $134.73 \mathrm{ppm}$ to $\mathrm{C}-3$ adjacent to the lactam carbonyl, 118.99 and 116.73 to the $s p^{2}$-hybridized carbon atoms $\mathrm{C}-7$ and $\mathrm{C}-4$, the doublet $102.08 \mathrm{ppm}$ to the methine $\mathrm{C}-9$ and the triplet $43.91 \mathrm{ppm}$ to the methylene C-5.

In the ${ }^{13} \mathrm{C}$ NMR spectrum of metabolite 6 all signals of the aromatic ring and the lactam ring $(\mathrm{C}-2$ and $\mathrm{C}-2$ ' to $\mathrm{C}-9$ and $\mathrm{C}-9^{\prime}$ ) and some signals of the decalene and the five-membered ring of the spirocyclic ring system are further split due to the pseudosymmetric bridge in the molecule. The most significant difference in chemical shifts was seen in the case of the carbon atoms C-5 (48.36 ppm) and C-5' (43.57 ppm) which can be explained by the influence of the adjacent carbon atom $\mathrm{C}-2^{\prime \prime}$ bearing a carboxylic group and by the proximity of the methylene group C-6".

HMBC correlations were measured for the carbon atoms C-5, C-9, C-10, C-13, C-15, C-17, C-18, C-19, $\mathrm{C}-21, \mathrm{C}-22, \mathrm{C}-23$ and $\mathrm{C}-24$ in compound 1 and are summarized in Table 2. These experiments enabled the full interpretation of the ${ }^{13} \mathrm{C}$ NMR spectrum of compound 1 including the decalene moiety of this molecule.

The shifts of the carbon atoms of the decalene moieties and the five-membered rings of the spirocyclic ring system compare well to those reported for Mer-NF5003E ${ }^{4}$. It 
Table 2. ${ }^{13} \mathrm{C}$ NMR chemical shifts of spirodihydrobenzofuranlactams I (1), III (3) and VI (6) and Mer-NF5003E (7).

\begin{tabular}{|c|c|c|c|c|c|}
\hline Carbon number & $1^{\mathrm{a}}$ & $3^{\text {a }}$ & $6^{\mathrm{b}}$ & 7 & $\begin{array}{l}\text { HMBC correlation for } \mathbf{1} \\
\text { correlated carbon number }\end{array}$ \\
\hline $2,2^{\prime}$ & $174.11 \mathrm{~s}$ & $171.09 \mathrm{~s}$ & $171.77 \mathrm{~s}, 171.03 \mathrm{~s}$ & $63.97 \mathrm{t}$ & \\
\hline $3,3^{\prime}$ & $134.73 \mathrm{~s}$ & $135.02 \mathrm{~s}$ & $135.11 \mathrm{~s}, 135.08 \mathrm{~s}$ & $146.8 \mathrm{~s}$ & \\
\hline $4,4^{\prime}$ & $116.73 \mathrm{~s}$ & $114.19 \mathrm{~s}$ & $114.97 \mathrm{~s}, 114.28 \mathrm{~s}$ & $108.54 \mathrm{~d}$ & \\
\hline $5,5^{\prime}$ & $43.91 \mathrm{t}$ & $43.17 \mathrm{t}$ & $48.36 \mathrm{t}, 43.57 \mathrm{t}$ & $188.77 \mathrm{~d}$ & $2,6,3,4$ \\
\hline $6,6^{\prime}$ & $157.78 \mathrm{~s}$ & $157.52 \mathrm{~s}$ & $157.57 \mathrm{~s}, 157.52 \mathrm{~s}$ & $169.64 \mathrm{~s}$ & \\
\hline $7,7^{\prime}$ & $118.99 \mathrm{~s}$ & $118.75 \mathrm{~s}$ & $118.86 \mathrm{~s}, 118.82 \mathrm{~s}$ & $112.64 \mathrm{~s}$ & \\
\hline $8,8^{\prime}$ & $155.20 \mathrm{~s}$ & $155.20 \mathrm{~s}$ & $155.13 \mathrm{~s}, 155.01 \mathrm{~s}$ & $159.95 \mathrm{~s}$ & \\
\hline $9,9^{\prime}$ & $102.08 \mathrm{~d}$ & $102.15 \mathrm{~d}$ & $102.41 \mathrm{~d}, 102.35 \mathrm{~d}$ & $110.37 \mathrm{~s}$ & $2,8,7,4$ \\
\hline $10,10^{\prime}$ & $32.99 \mathrm{t}$ & $32.95 \mathrm{t}$ & $33.04 \mathrm{t}, 32.97 \mathrm{t}$ & $31.31 \mathrm{t}$ & $6,8,7,11,12,16$ \\
\hline $11,11^{\prime}$ & $99.68 \mathrm{~s}$ & $99.71 \mathrm{~s}$ & $99.74 \mathrm{~s}$ & $100.42 \mathrm{~s}$ & \\
\hline $12,12^{\prime}$ & $38.39 \mathrm{~d}$ & $38.35 \mathrm{~d}$ & $38.47 \mathrm{~d}, 38.39 \mathrm{~d}$ & $37.77 \mathrm{~d}$ & \\
\hline $13,13^{\prime}$ & $32.26 \mathrm{t}$ & $32.25 \mathrm{t}$ & $32.30 \mathrm{t}$ & $32.10 \mathrm{t}$ & 14 \\
\hline $14,14^{\prime}$ & $22.11 \mathrm{t}$ & $22.09 \mathrm{t}$ & $22.16 \mathrm{t}$ & $21.71 \mathrm{t}$ & \\
\hline $15,15^{\prime}$ & $41.35 \mathrm{~d}$ & $41.34 \mathrm{~d}$ & $41.49 \mathrm{~d}, 41.40 \mathrm{~d}$ & $40.87 \mathrm{~d}$ & 14 \\
\hline $16,16^{\prime}$ & $43.52 \mathrm{~s}$ & $43.51 \mathrm{~s}$ & $43.55 \mathrm{~s}$ & $43.20 \mathrm{~s}$ & \\
\hline $17,17^{\prime}$ & $25.37 \mathrm{t}$ & $25.35 \mathrm{t}$ & $25.46 \mathrm{t}$ & $24.98 \mathrm{t}$ & 18 \\
\hline $18,18^{\prime}$ & $26.04 t$ & $26.01 \mathrm{t}$ & $26.16 \mathrm{t}, 26.08 \mathrm{t}$ & $26.02 \mathrm{t}$ & 17 \\
\hline $19,19^{\prime}$ & $76.46 \mathrm{~d}$ & $76.45 \mathrm{~d}$ & $76.49 \mathrm{~d}, 76.42 \mathrm{~d}$ & $75.33 \mathrm{~d}$ & 15,17 \\
\hline $20,20^{\prime}$ & $38.65 \mathrm{~s}$ & $38.64 \mathrm{~s}$ & $38.67 \mathrm{~s}$ & $38.33 \mathrm{~s}$ & \\
\hline $21,21^{\prime}$ & $15.96 \mathrm{q}$ & $15.96 \mathrm{q}$ & $15.99 \mathrm{q}$ & $16.00 \mathrm{q}$ & $11,12,13$ \\
\hline $22,22^{\prime}$ & $16.54 \mathrm{q}$ & $16.52 \mathrm{q}$ & $16.62 \mathrm{q}$ & $16.44 \mathrm{q}$ & $11,15,16,17$ \\
\hline $23,23^{\prime}$ & $28.97 \mathrm{q}$ & $28.97 \mathrm{q}$ & $28.96 \mathrm{q}$ & $29.04 \mathrm{q}$ & $15,19,20,24$ \\
\hline $24,24^{\prime}$ & $22.98 \mathrm{q}$ & $22.96 \mathrm{q}$ & $22.99 \mathrm{q}$ & $22.82 \mathrm{q}$ & $15,19,20,23$ \\
\hline $1^{\prime \prime}$ & & $48^{\mathrm{c}} \mathrm{t}$ & $179.0 \mathrm{~s}$ & & \\
\hline $2^{\prime \prime}$ & & $28.87 \mathrm{t}$ & $58.23 \mathrm{~d}$ & & \\
\hline $3^{\prime \prime}$ & & $23.49 \mathrm{t}$ & $28.82 \mathrm{t}$ & & \\
\hline $4^{\prime \prime}$ & & $35.20 \mathrm{t}$ & $25.12 \mathrm{t}$ & & \\
\hline $5^{\prime \prime}$ & & $178.97 \mathrm{~s}$ & $30.87 \mathrm{t}$ & & \\
\hline $6^{\prime \prime}$ & & & $46.23 \mathrm{t}$ & & \\
\hline
\end{tabular}

Chemical shifts given in ppm. ${ }^{\text {a Solvent }} \mathrm{CD}_{3} \mathrm{OD},{ }^{\mathrm{b}}$ solvent $\mathrm{CD}_{3} \mathrm{OD}, 45^{\circ} \mathrm{C},{ }^{\mathrm{c}}$ hidden under solvent peak.

is not surprising, that the chemical shifts of the aromatic ring differ substantially in the spirodihydrobenzofuranlactams 1,3 and $\mathbf{6}$ compared to those of Mer$\mathrm{NF} 5003 \mathrm{~B}, \mathrm{E}$ and $\mathrm{F}$, since the aromatic ring is either in the neighborhood of an annelated five-membered ring lactam or substituted by either two aldehyde groups or an alcohol and an aldehyde function.

The chemical shifts of the carbon atoms of the bridged lysine bridge in compound 6 are assigned on the basis of the reported data for lysine ${ }^{5)}$ and are in the same order of magnitude. The values and assignments of the chemical shifts of the side chain of the spirodihydrobenzofuranlactam III (3) are in agreement with the published data for homoglutamic acid and ornithine ${ }^{6)}$.

The structures of the six novel spirodihydrobenzofuranlactams I $\sim$ VI $(1 \sim 6)$ and the final stereochemistry of compound 1 have been established by the evaluation of their IR-, FAB-MS or HR-FAB-MS, different one and two dimensional ${ }^{1} \mathrm{H}$ NMR- and ${ }^{13} \mathrm{C}$ NMR-spectra and by NOE measurements. A comparison to previously described fungal metabolites has been made.

\section{Experimental}

The following instruments were used in this study: Bruker spectrometer IFS 48, VG 70-SE (FISONS Instruments, Mainz-Kastel), Finnigan MAT 90 or Varian MAT CH7 mass spectrometers, Varian VXR-400 S NMR spectrometer.

\section{Spectroscopic Data of 1}

Crystals from EtOAc. IR $v_{\max }(\mathrm{KBr}) \mathrm{cm}^{-1}: 3389,2935$, 2874, 1682, 1466, 1387, 1348, 1333, 1261, 1146, 1128, $1086,1038,1009,989,960,945,878,773$; FAB-MS $m / z$ $386(\mathrm{M}+\mathrm{H})^{+}$; HR-FAB-MS $m / z 386.2330\left(\mathrm{C}_{23} \mathrm{H}_{32} \mathrm{NO}_{4}\right.$, $\left.\delta_{\mathrm{m}}=1 \mathrm{mmu}\right) ;{ }^{1} \mathrm{H}$ NMR $\left(400 \mathrm{MHz}, \mathrm{DMSO}, 80^{\circ} \mathrm{C}\right)$ : see Table $1 ;{ }^{13} \mathrm{C}$ NMR $\left(100 \mathrm{MHz}, \mathrm{CD}_{3} \mathrm{OD}\right)$ : see Table 2.

Data of 2

Lyophilized white powder. IR $v_{\max }(\mathrm{KBr}) \mathrm{cm}^{-1}$ : 1078, 1038, 1013, 988, 943, 895, 771; FAB-MS $m / z 430$ $(\mathrm{M}+\mathrm{H})^{+}$; HR-FAB-MS $m / z \quad 430.2592\left(\mathrm{C}_{25} \mathrm{H}_{36} \mathrm{NO}_{5}\right.$, $\left.\delta_{\mathrm{m}}=1 \mathrm{mmu}\right) ;{ }^{1} \mathrm{H}$ NMR $\left(400 \mathrm{MHz}, \mathrm{CD}_{3} \mathrm{OD}\right)$ : see Table 1 .

\section{Data of 3}

Lyophilized white powder. IR $v_{\max }(\mathrm{KBr}) \mathrm{cm}^{-1}: 3425$, $2935,2874,1664,1468,1423,1389,1348,1333,1258$, 
1165, 1078, 988, 939, 905, 851, 770, 708; FAB-MS $m / z$ $486(\mathrm{M}+\mathrm{H})^{+} ; \mathrm{HR}-\mathrm{FAB}-\mathrm{MS} m / z 486.2864\left(\mathrm{C}_{28} \mathrm{H}_{40} \mathrm{NO}_{6}\right.$, $\left.\delta_{\mathrm{m}}=8 \mathrm{mmu}\right) ;{ }^{1} \mathrm{H}$ NMR (400 MHz, $\left.\mathrm{CD}_{3} \mathrm{OD}\right)$ : see Table 1; ${ }^{13} \mathrm{C}$ NMR $\left(100 \mathrm{MHz}, \mathrm{CD}_{3} \mathrm{OD}\right)$ : see Table 2.

\section{Data of 4}

Lyophilized white powder. IR $v_{\max }(\mathrm{KBr}) \mathrm{cm}^{-1}: 3416$, 2935, 2876, 1661, 1614, 1466, 1412, 1348, 1333, 1259, 1146, 1086, 940, 771; FAB-MS $m / z 516(\mathrm{M}+\mathrm{H})^{+}$; HR-FAB-MS $m / z 516.2601\left(\mathrm{C}_{28} \mathrm{H}_{38} \mathrm{NO}_{8}, \delta_{\mathrm{m}}=4 \mathrm{mmu}\right)$; ${ }^{1} \mathrm{H}$ NMR (400 MHz, $\left.\mathrm{CD}_{3} \mathrm{OD}\right)$ : see Table 1 .

\section{Data of 5}

Crystals from EtOAc. IR $v_{\max }(\mathrm{KBr}) \mathrm{cm}^{-1}$ : 3415 , $3250,2920,2886,1755,1715,1620,1455,1318,1255$, 1146, 1128, 1086, 1070, 1050, 989, 960, 945, 870, 760; FAB-MS $m / z \quad 400(\mathrm{M}+\mathrm{H})^{+}$; HR-FAB-MS $m / z$ $400.2128\left(\mathrm{C}_{23} \mathrm{H}_{30} \mathrm{NO}_{5}, \delta_{\mathrm{m}}=4 \mathrm{mmu}\right) ;{ }^{1} \mathrm{H}$ NMR $(400$ $\mathrm{MHz}, \mathrm{DMSO} / \mathrm{CDCl}_{3}$ ): see Table 1 .

\section{Data of 6}

Lyophilized white powder. IR $v_{\max }(\mathrm{KBr}) \mathrm{cm}^{-1}: 3423$, 2935, 2870, 1669, 1468, 1420, 1387, 1348, 1145, 1080, 1013, 986, 941, 905, 841, 771; FAB-MS $m / z 883$ $(\mathrm{M}+\mathrm{H})^{+}$; HR-FAB-MS $m / z 883.5120\left(\mathrm{C}_{52} \mathrm{H}_{71} \mathrm{~N}_{2} \mathrm{O}_{10}\right.$, $\left.\delta_{\mathrm{m}}=1 \mathrm{mmu}\right) ;{ }^{1} \mathrm{H}$ NMR $\left(400 \mathrm{MHz}, \mathrm{CD}_{3} \mathrm{OD}\right)$ : see Table $1 ;{ }^{13} \mathrm{C} \mathrm{NMR}\left(100 \mathrm{MHz}, \mathrm{CD}_{3} \mathrm{OD}, 45^{\circ} \mathrm{C}\right)$ : see Table 2.

\section{References}

1) Roggo, B. E.; F. Petersen, M. Sills, J. L. Roesel, T. Moerker \& H. H. Peter: Novel spirodihydrobenzofuranlactams as antagonists of endothelin and as inhibitors of HIV-1 protease produced by Stachybotrys sp. I. Fermentation, isolation and biological activity. J. Antibiotics 49: $13 \sim 19,1996$

2) Giocobbe, R. A.; L. Huang, Y, L. Kong, Y. T. Lam, S. M. Del Val, C. F. Wichman \& D. L. ZinK (Merck \& Co., Inc.): Drug for treating manic depression. U.S. 4,981,980, publication date January 1, 1991

3) Kaise, H:; M. Shinohara, W. MiyazaKi, T. Izawa, Y. Nakano, M. Sugawara, K. Sugiura \& K. Sasaki: Structure of K-76, a complement inhibitor produced by Stachybotrys complementi, nov. sp. K-76. J. Chem. Soc. Chem. D. Commun. 1979: 726 727, 1979

4) Kaneto, R.; K. Dobashi, I. Kojima, K. Sakai, N. Shibamoto, T. Yoshioka, H. Nishida, R. OKamoto, H. Akagawa \& S. Mizuno: Mer-NF5003B, E and F, novel sesquiterpenoids as avian myeloblastosis virus protease inhibitors produced by Stachybotrys sp. J. Antibiotics 47: $727 \sim 730,1994$

5) Kalinowski, H.-O.; S. Berger \& S. Braun: ${ }^{13} \mathrm{C}$ NMR-Spektroskopie. page 208, Georg Thieme Verlag Stuttgart New York, 1984

6) Kalinowski, H.-O.; S. Berger \& S. Braun: ${ }^{13} \mathrm{C}$ NMR-Spektroskopie. page 209, Georg Thieme Verlag Stuttgart New York, 1984 